\title{
IMPLEMENTASI KEBIJAKAN PENGEMBANGAN DAN PEMBANGUNAN PARIWISATA BERKELANJUTAN YANG BERBASIS KEARIFAN LOKAL DI BALI (Studi kasus: Desa Jatiluwih, Kabupaten Tabanan)
}

\author{
Kadek Wiwin Dwi Wismayanti \\ Program Studi Administrasi Publik \\ Fakultas Ilmu Sosial dan Ilmu Politik, Univeritas Udayana \\ Email:wiwin.fisip@gmail.com
}

\begin{abstract}
ABSTRAK
Penyelenggaraan kepariwisataan dalam Undang-Undang No 10 tahun 2009 secara terperinci dijelaskan pada Bab III pasal 5 tentang prinsip penyelenggaraan kepariwisataan. Menyatakan bahwa kepariwisataan diselenggarakan dengan prinsip menjunjung tinggi norma agama dan nilai budaya sebagai pengejawantahan konsep Tri Hita Karana; menjunjung tinggi hak asasi manusia, keragaman budaya, dan kearifan lokal; memelihara kelestarian alam dan lingkungannya; memberdayakan masyarakat setempat; menjamin keterpaduan antarsektor, antardaerah, antara pusat dan daerah yamg merupakan satu kesatuan sistemik dalam kerangka otonomi daerah, serta keterpaduan antarpemangku kepentingan. Pada dasarnya penyelenggaraan kepariwisataan di desa ini ditujukan untuk meningkatkan taraf hidup serta kesejahteraan rakyat melalui pengembangan ekonomi melalui pengembangan dan pembangunan pariwisata berkelanjutan yang berbasis kearifan lokal. Pelaksanaan penyelenggaraan kepariwisataan ini kemudian dijalankan oleh kelembagaan pariwisata guna terciptanya pembangunan pariwisata yang berkelanjutan.Penelitian ini merupakan jenis penelitian deskriptif kualitatif dengan metode pengumpulan data berupa observasi, wawancara, dan dokumentasi. Informan dalam penelitian ini ditentukan melalui teknik purposive dan snowball sampling. Penelitian ini dilakukan di Desa Jatiluwih, Kecamatan Penebel, Kabupaten Tabanan. Ada Tiga indikator yang digunakan dalam penelitian, yaitu: Implementasi kebijakan yang terdiri dari Komunikasi, Sumberdaya, Disposisi, struktur birokrasi sudah diterapkan dengan baik..
\end{abstract}

Kata Kunci : Implementasi kebijakan, Pariwisata berkelanjutan, kearifan lokal

\section{ABSTRACT}

The implementation of tourism in Law No. 10 of 2009 in detail is explained in Chapter III of article 5 on the principle of the implementation of tourism. Stating that tourism is carried out with the principle of upholding religious norms and cultural values as an embodiment of the Tri Hita Karana concept; uphold human rights, cultural diversity and local wisdom; maintain the preservation of nature and the environment; empower the local community; ensuring integration between sectors, between regions, between the center and regions which constitutes a systemic unit within the framework of regional autonomy, as well as integration among stakeholders. Basically the organization of tourism in the village is aimed at improving the standard of living and welfare of the people through economic development through the development and development of sustainable tourism based on local wisdom. The implementation of tourism is then carried out by tourism institutions in order to create sustainable tourism development.This research is a type of descriptive qualitative research with data collection methods in the form of observation, interviews, and documentation. Informants in this study were determined through purposive techniques and snowball sampling. This research was conducted in Jatiluwih Village, Penebel District, Tabanan Regency. There are three indicators used in the study, namely: Implementation of policies consisting of Communication, Resources, Disposition, bureaucratic structures have been applied properly.

Keywords: Policy implementation, sustainable tourism, local wisdom 


\section{PENDAHULUAN}

Kabupaten Tabanan merupakan salah satu daerah yang menerima gagasan untuk beberapa desanya dijadikan sebagai Desa Wisata yang mana Tabanan sendiri mendapatkan jatah 16 desa yang harus dikembangkan menjadi Desa Wisata. Jika dilihat dari jumlah wisatawan untuk objek wisata yang ada di Kabupaten Tabanan tercatat jika jumlah kunjungan wisatawan nusantara dan wisatawan mancanegara di Kabupaten Tabanan mengalami peningkatan tiap tahunnya. Berikut adalah data jumlah pengunjung wisatawan mancanegara dan wisatawan nusantara pada obyek wisata di Kabupaten Tabanan dari tahun 2012 sampai dengan tahun 2016.

Tabel 1.1

Kunjungan Wisatawan Nusantara dan Mancanegara Pada Obyek Wisata di Kabupaten Tabanan, Tahun 2012 s/d 2016

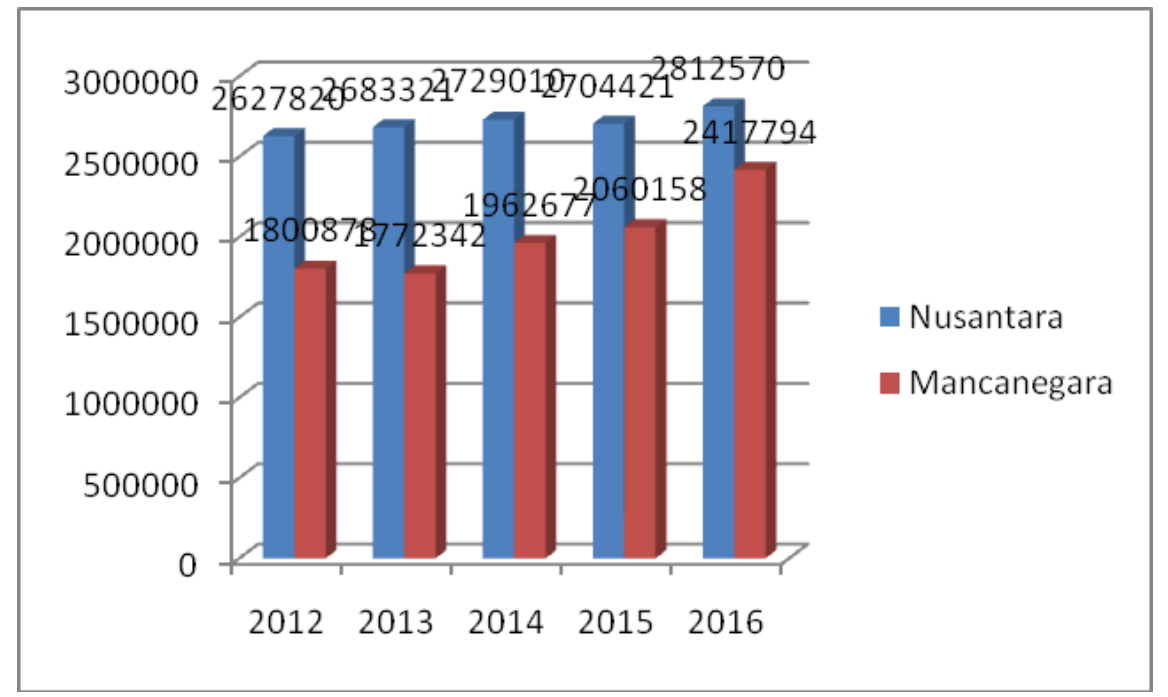

Sumber Data: Dinas Pariwisata Kabupaten Tabanan

Walaupun di tahun 2013 untuk kunjungan wisatawan mancanegara dan di tahun 2015 untuk kunjungan nusantara mengalami penurunan namun tidak signifikan dan di tahun berikutnya masing-masing mengalami peningkatan hingga tahun 2016.

Desa Jatiluwih merupakan salah satu desa yang disahkan sebagai desa wisata di Kabupaten Tabanan pada tahun 2016 dengan dikeluarkannya SK Bupati No 138/337/03 Tahun 2016. Namun jauh sebelum disahkannya sebagai desa wisata, Desa Jatiluwih telah lebih dulu dikenalkan sebagai Daya Tarik Wisata (DTW) sejak tahun 1997 dan pada tahun 2012 Bali mendapat pengakuan istimewa dari UNESCO dengan penetapan subak sebagai warisan budaya dunia dengan label Cultural Landscape of Bali Privince: The Subak System as a Manifestation of the Tri Hita Karana Philosophy (Lanskap budaya Bali: Sistem Subak sebagai Manifestasi Filosopi Tri Hita Karana) dan Jatiluwih termasuk di dalam kawasan Lanskap Subak dari Catur Angga Batukaru yang merupakan salah satu dari lima kawasan di Bali yang ditetapkan oleh UNESCO menjadi Warisan Budaya Dunia (WBD) tersebut 


\section{METODE PENELITIAN}

Metode penelitian yang digunakan dalam penelitian ini adalah penelitian kualitatif Singarimbun dan Efendi:1989:4 menyatakan dimana bahwa penelitian kualitatif merupakan penelitian dengan pendekatan deskriptif, penelitian deskriptif yang dimaksudkan sebagai pengukuran fenomena sosial tertentu yang mampu mengembangkan konsep serta menghimpun fakta tetapi tidak melakukan hipotesis, sebagaimana hasil wawancara akan digunakan serta dijabarkan sehingga menghasilkan analisis deskriptif sebagaimana dalam penelitian kualitatif.Teknik pengumpulan data dalam Penelitian ini dilakukan dengan mengumpulkan data primer dan data sekunder. Pengumpulan data yang dilakukan dalam penelitian ini menggunakan teknik-teknik pengumpulan data sebagai berikut: Observasi langsung ke lokasi penelitian pada Jatiluwih Kabupaten Tabanan dalam rangka penelusuran data yang tidak diperoleh dalam wawancara, maupun data-data sekunder. Wawancara mendalam (in-depth interview) yang dilakukan terhadap narasumber untuk mengetahui secara persis fenomena-fenomena tentang pengemabngan Desa Jatiluwih yang ingin diketahui. Data yang akan diperoleh langsung dari informan menjadi sumber data dalam penelitian ini adalah para aktor dalam proses pengembangan Desa Jatiluwih berbasis Kearifan lokal. .

\section{HASIL DAN PEMBAHASAN \\ 1. Implementasi Kebijakan}

\section{Komunikasi}

Indikator konsistensi yang digunakan untuk mengukur keberhasilan komunikasi adalah konsistensi informasi yang disampaikan, dimana bimbingan dan pendampingan dari Pemerintah Kabupaten Tabanan masih sangat diperlukan di Jatiluwih sampai saat ini meskipun dirasa sudah lumayan optimal dikarenakan mengingat Jatiluwih masih dalam tahap pengembangan sehingga antara pemerintah Kabupaten Tabanan dengan pemerintah Desa Jatiluwih dan masyarakatanya terjalin komunikasi yang searah dan adanya konsistensi informasi. Begitu pula dengan pemerintah desa dengan para petani yang merupakan sebagai leading sector yang membantu dalam mendukung keberhasilan pariwisata berbasis kearifan lokal mengingat sawah menjadi objek sentral atau ikon pada daerah tujuan wisata Jatiluwih. Komunikasi antara petani dan pemerintah desa Jatiluwih sampai saat ini masih terjalin dengan baik dan selalu akan mengadakan rapat-rapat apabila terdapat usulan dari petani kepada pemerintah desa begitu juga sebaliknya yaitu terdapat informasi yang perlu disampaikan oleh pemerintah desa kepada petani, maka akan diadakan rapat antara pekaseh masing-masing subak selaku perwakilan dari petani di masingmasing subak sehingga adanya konsistensi informasi.

\section{Disposisi}

Berdasarkan hasil penelitian di lapangan, sikap dari pihak desa dalam mengimplementasikan kebijakan pengembangan dan pembangunan pariwisata 
berkelanjutan berbasis kearifan lokal di Jatiluwih dapat dikatakan cukup positif, melihat bagaimana pihak desa begitu berupaya bersama dengan masyarakat desa Jatiluwih untuk mengembangkan pariwisata tanpa harus merusak dan menghilangkan kearifan lokalnya melainkan mengelola kearifan lokal yang dimiliki menjadi potensi dan daya tarik wisata sehingga hal ini sesuai dengan kebijakan yang ditetapkan dan dijalankan di Jatiluwih yaiutu kebijakan pengembangan dan pembangunan pariwisata berkelanjutan yang berbasis kearifan lokal. Pihak desa masih tetap mempertahankan kearifan lokalnya yaitu subak dan terasering sebagai objek wisata serta ditambah dengan keberadaan rute track di tengah hamparan sawah tanpa harus merusak sawah-sawah di sekitarnya yang merupakan sebagai tempat sumber mata pencaharian masyarakat jatiluwih, sehingga adanya sinergitas antara pariwisata dan pertanian terutamanya dalam bidang sawah dan subak. Pihak desa dan Pemerintah Kabupaten Tabanan tidak hanya berfokus pada pengembangan pariwisata saja melainkan juga tetap memperhatikan komponen yang mendukungnya seperti sawah dan subak yang menjadi kearifan lokal di Jatiluwih.

\section{Sumber Daya}

Permasalahan staf atau sumber daya manusia (SDM) dalam menjalankan dan mengimplementasikan suatu kebijakan tidak hanya menyangkut besaran atau jumlahnya saja, melainkan juga dilihat berdasarkan kapasitas atau kompetensi sumber daya tersebut. Dilihat dari jumlah staf atau pegawai di daerah tujuan wisata Jatiluwih sudah dirasa cukup memadai. Terdapat pembagian tugas yang jelas diantara pemerintah desa dengan Badan Pengelolaan DTW Jatiluwih, dimana pada pemerintah desa para pegawainya fokus menangani persoalan administrasi desa sehingga untuk administrasi atau birokrasi desa dapat dimaksimalkan sedangkan pegawai atau staf di Badan Pengelolaan DTW Jatiluwih lebih mengarah ke pengelolaan daerah tujuan wisata Jatiluwih, jadinya antara birokrasi desa dengan pengelolaan daerah tujuan wisata Jatiluwih menjadi terarah dan tidak bercampur. Terkait jumlah pegawai atau staf yang terdapat di Badan Pengelolaan DTW Jatiluwih cukup memadai dan sudah terbagi sesuai dengan kebutuhan yang mendukung dalam pengelolaan daerah tujuan wisata Jatiluwih yaitu terdiri atas manajer operasional, asisten 1, asisten 2, kepala divisi hingga staf dan karyawan. Berdasarkan jumlah pegawai yang dimiliki di desa jatiluwih khususnya pegawai di Badan Pengelolaan DTW Jatiluwih, hampir semuanya sudah cukup berkompeten dan sudah menjalankan tugasnya sesuai tupoksinya masing-masing dalam mendukung terlaksananya implementasi kebijakan pengembangan dan pembangunan pariwisata yang berbasis kearifan lokal di Jatiluwih. Sebagian besar pegawainya mampu berkomunikasi menggunakan bahasa inggris dengan baik dan lancar. Selain itu, pegawai atau staf di Badan Pengelola DTW Jatiluwih semuanya direkrut melalui proses seleksi oleh panitia seleksi yang terdiri dari akademisi, tokok agama, tokoh masyarakat, dan tokoh kepariwisataan serta tidak terlepas atas arahan Pemkab Tabanan

\section{Struktur Birokrasi}


Pelaksanaan sebuah kebijakan sudah tentu harus diberikan batasan dalam hal pelaksanaanya, dalam pelaksanaan program hal ini kemudian dikenal dengan sebutan Standar Operating Procerures (SOPs). Dalam pelaksanaan pengembangan dan pembangunan pariwisata berkelanjutan berbasis kearifan lokal di Jatiluwih, dibentuk perjanjian lima pihak yaitu Desa Dinas, Desa Adat Jatiluwih, Desa Adat Gunung Sari, Subak Jatiluwih, dan bekerjasama dengan Pemerintah Kabupaten Tabanan. Perjanjian lima pihak membentuk sebuah manajemen pengelolaan yang independen yang disebut Badan Pengelola DTW Jatiluwih. Dalam pengelolaan ini juga terbentuk perjanjian-perjanjian, dimana lima pihak tersebut akan mendapat pah-pahan atau bagi hasil pendapatan yang didapatkan dari pengelolaan Desa Jatiluwih yang digunakan untuk menunjang segala jenis pembangunan dan kegiatan upacaranya.

\section{SIMPULAN}

Komunikasi antara petani dan pemerintah desa Jatiluwih sampai saat ini masih terjalin dengan baik dan selalu akan mengadakan rapat-rapat apabila terdapat usulan dari petani kepada pemerintah desa begitu juga sebaliknya yaitu terdapat informasi yang perlu disampaikan oleh pemerintah desa kepada petani, maka akan diadakan rapat antara pekaseh masing-masing subak selaku perwakilan dari petani di masing-masing subak sehingga adanya konsistensi informasi. Dari struktur Disposisi pihak desa begitu berupaya bersama dengan masyarakat desa Jatiluwih untuk mengembangkan pariwisata tanpa harus merusak dan menghilangkan kearifan lokalnya melainkan mengelola kearifan lokal yang dimiliki menjadi potensi dan daya tarik wisata sehingga hal ini sesuai dengan kebijakan yang ditetapkan dan dijalankan di Jatiluwih yaiutu kebijakan pengembangan dan pembangunan pariwisata berkelanjutan yang berbasis kearifan lokal.

Indikator Sumber Daya yang dilihat dari jumlah staf atau pegawai di daerah tujuan wisata Jatiluwih sudah dirasa cukup memadai. Terdapat pembagian tugas yang jelas diantara pemerintah desa dengan Badan Pengelolaan DTW Jatiluwih, dimana pada pemerintah desa para pegawainya fokus menangani persoalan administrasi desa sehingga untuk administrasi atau birokrasi desa dapat dimaksimalkan sedangkan pegawai atau staf di Badan Pengelolaan DTW Jatiluwih lebih mengarah ke pengelolaan daerah tujuan wisata Jatiluwih, jadinya antara birokrasi desa dengan pengelolaan daerah tujuan wisata Jatiluwih menjadi terarah dan tidak bercampur. Dari segi Struktur birokrasi dapat dilihat dari dalam pelaksanaan pengembangan dan pembangunan pariwisata berkelanjutan berbasis kearifan lokal di Jatiluwih, dibentuk perjanjian lima pihak yaitu Desa Dinas, Desa Adat Jatiluwih, Desa Adat Gunung Sari, Subak Jatiluwih, dan bekerjasama dengan Pemerintah Kabupaten Tabanan. Perjanjian lima pihak membentuk sebuah manajemen pengelolaan yang independen yang disebut Badan Pengelola DTW Jatiluwih.

\section{Referensi}

Agustino, Leo. 2012. Dasar-Dasar Kebijakan Publik. Bandung. Alfabeta 
Dunn, William. 2003. Pengantar Analisis Kebijakan Publik Edisi Kedua. Yogyakarta: Gajah Mada University Press

Judisseno. 2017. “Aktivitas Dan Kompleksitas Kepariwisataan”. Jakarta: PT Gramedia Pustaka Utama

Nuryanti, Wiendu. 1993. Desa Wisata dan Lingkungannya. Jakarta: Gramedia

UNESCO. 2017. "Strategi Pariwisata Berkelanjutan, Lanskap Budaya Provinsi Bali: Sistem Subak Sebagai Manifestasi dari Filosofi Tri Hita Karana" Jakarta. Kantor UNESCO Jakarta

UNWTO. 2005. Making Tourism More Sustainable: A Guide for Policy Makers. [Buku Online] Tersedia di: http://www.unep.fr/shared/publications/pdf/dtix0592xpatourismpolicyen.pdf

Peraturan Daerah Provinsi Bali No. 10 Tahun 2015 tentang Rencana Induk Pembangunan Kepariwisataan Daerah Provinsi Bali Tahun 2015-2029

Peraturan Daerah Kabupaten Tabanan No. 6 Tahun 2014 Tentang Kawasan Jalur Hijau SK Bupati No 138/337/03 Tahun 2016

Undang-Undang Republik Indonesia No 10. Tahun 2009 Tentang Kepariwisataan Undang-Undang No 6 Tahun 2014 Tentang Kawasan Jalur Hijau

Undang-Undang Republik Indonesia No. 6 Tahun 2014 Tentang Desa 